\title{
Utilising spatial distribution in two-tank systems to investigate the level of aversiveness to crowding in farmed rainbow trout Oncorhynchus mykiss
}

Laursen, Danielle Caroline; Andersson, Madelene Åberg; Silva, Patricia Isabel Mota; Petersson, Erik; Höglund, Erik

Published in:

Applied Animal Behaviour Science

Link to article, DOI:

10.1016/j.applanim.2013.01.010

Publication date:

2013

Link back to DTU Orbit

Citation (APA):

Laursen, D. C., Andersson, M. Å., Silva, P. I. M., Petersson, E., \& Höglund, E. (2013). Utilising spatial distribution in two-tank systems to investigate the level of aversiveness to crowding in farmed rainbow trout Oncorhynchus mykiss. Applied Animal Behaviour Science, 144(3-4), 163-170.

https://doi.org/10.1016/j.applanim.2013.01.010

\section{General rights}

Copyright and moral rights for the publications made accessible in the public portal are retained by the authors and/or other copyright owners and it is a condition of accessing publications that users recognise and abide by the legal requirements associated with these rights.

- Users may download and print one copy of any publication from the public portal for the purpose of private study or research.

- You may not further distribute the material or use it for any profit-making activity or commercial gain

- You may freely distribute the URL identifying the publication in the public portal 
1 Utilising spatial distribution in two-tank systems to investigate the level of aversiveness to crowding in

2 farmed rainbow trout Oncorhynchus mykiss

3

4 Danielle Caroline Laursen ${ }^{1 *}$, Madelene Åberg Andersson ${ }^{1}$, Patricia Isabel Mota Silva ${ }^{1,2,3}$, Erik Petersson ${ }^{4}$ and $5 \quad$ Erik Höglund ${ }^{1}$

6

$7{ }^{1}$ Danish Technical University, DTU Aqua, Institute of Aquatic Resources, Section for Aquaculture, The

$8 \quad$ North Sea Research Center, P.O. Box 101, 9850 Hirtshals, Denmark

$9 \quad{ }^{2}$ Department of Animal and Aquacultural Sciences, Norwegian University of Life Sciences, P.O. Box 5003, 101432 As, Norway

$11{ }^{3}$ Centro de Ciências do Mar (CCMAR), Universidade do Algarve, Campus de Gambelas, 8005-139 Faro, 12 Portugal

$13{ }^{4}$ Swedish University of Agricultural Sciences, Department of Aquatic Resources, 17893 Drottningholm, 14 Sweden

*Corresponding author: Danish Technical University, DTU Aqua, Institute of Aquatic Resources, Section for 
Abstract

In aquaculture, fish are exposed to a range of unfavourable environmental conditions.

Amongst these, stocking density has attracted considerable attention as inappropriate densities may compromise welfare and negatively impact production. However, the recommendations for stocking remain elusive. The aim of the present study was to apply a novel method to investigate a level of crowding that indicated aversiveness in rainbow trout (Oncorhynchus mykiss). In a two-tank system, where two identical tanks were connected via a doorway, it was observed that social behaviour controlled the distribution of the fish between the tanks. Fish were stocked at equal quantities in each tank of the system. The doorway was opened and the fish moved between the two tanks. Typically, this resulted in one tank being occupied by a few highly aggressive dominant individuals (“dominant" tank) and the majority of the fish occupying the second tank ("crowded" tank). Here, the potential of this unequal spatial distribution for quantifying aversion to crowding was explored. Fish were stocked in three two-choice systems at a total density of 20, 40 and 80 $\mathrm{kg} \mathrm{m}^{-3}$ respectively. The number of fish in each tank was determined every three days throughout the duration of the experiment and the percentage of fish in the "crowded" tank was used as an indicator of the distribution pattern in the two-tank systems. The results indicated a negative relationship between the total density stocked $\left(20,40 \& 80 \mathrm{~kg} \mathrm{~m}^{-3}\right)$ and the percentage of fish in the "crowded" tank. A subsample of individuals was sacrificed for blood and brain samples every three days from the "crowded" tank, prior to the fish count. The neuroendocrine indicators of stress, elevated serotonergic activity levels which were not associated with high plasma levels of cortisol, suggested chronic stress in the fish at the highest total density stocked $\left(80 \mathrm{~kg} \mathrm{~m}^{-3}\right)$. Taken together, these results indicated that a level of aversiveness to crowding had been reached at the highest density stocked, where the mean absolute density, irrespective of time of day, observed in the "crowded" tank was $126.5 \pm 3.7 \mathrm{~kg} \mathrm{~m}^{-3}$.

Keywords Stocking density, aquaculture, behaviour, spatial distribution, aversiveness, stress 
1. Introduction

Stocking density in aquaculture has received considerable attention in recent years. This has been the consequence of an increasing public concern for the welfare of fish from aquaculture (Huntingford et al., 2006) and recognition in the commercial and scientific communities that inappropriate densities contribute to a reduced welfare status in fish (Ellis et al., 2002).

The general perception is that welfare decreases with increasing density, though there are no unanimous results of the effect of increasing stocking densities on indicators of welfare, such as general performance and stress hormone levels (Ellis et al., 2002). Naturally, this may in part be due to species differences, where welfare may be optimal for some species at higher densities and for others at lower densities. However, contradictory results have been found even within a species (Ellis et al., 2002; Brännäs and Johnsson, 2008). This has been attributed to differences between studies in experimental design and methodology (Ellis et al., 2002). However, it has also highlighted the fact that stocking density is a complex issue and the negative effects on welfare are likely to be the cause of a combination of factors as a consequence of stocking density (Bagley et al., 1994; Person-Le Ruyet et al., 2008), such as water quality and social interactions (Ellis et al., 2002).

The method that has most commonly been used to study the relationship between stocking density and welfare has been by investigating the effects of varying density levels on indicators of welfare; such as performance, condition, health and stress levels (Boujard et al., 2002; Ellis et al., 2002; Larsen et al., 2012; McKenzie et al., 2012; North et al., 2006; Person-Le Ruyet et al., 2008; Skøtt Rasmussen et al., 2007). Through such studies it has been possible to make general conclusions about the influence of stocking density on welfare. Ellis et al. (2002) reviewed all the studies to date that had investigated the relationship between stocking density and welfare for rainbow trout, Oncorhynchus mykiss. They concluded that despite the lack of clear evidence, high stocking density had the potential to reduce welfare. Since then, additional studies have been carried out, which concluded that low as well as high stocking densities had the potential to compromise indicators of welfare (Boujard et al., 2002; Ellis et al., 2002; Larsen et al., 2012; McKenzie et al., 2012; North et al., 2006; Person-Le Ruyet et al., 2008; Skøtt Rasmussen et al., 2007). 
recommendations for maximum stocking densities for rainbow trout based on their experimental results (Ellis et al., 2002). Depending on the type of rearing system, the recommendations for appropriate stocking densities made by the studies reviewed ranged from 4 to more than $267 \mathrm{~kg} \mathrm{~m}^{-3}$ (Ellis et al., 2002). Evidently, concrete conclusions regarding the density limits at which welfare and production in rainbow trout are optimised continue to be ambiguous. Therefore, developing alternative methods to investigate the density levels that fish experience as critically crowded may provide insight into optimal density limits for rainbow trout.

The aim of the current study was to apply a novel method to investigate a level of aversiveness to crowding of farmed rainbow trout (Oncorhynchus mykiss). This was achieved by studying the spatial distribution in two-tank systems stocked fish at different densities to establish a level of aversion to crowding. Here, a two-tank system consisted of two identical tanks which were attached to each other with a doorway, allowing individuals to move freely between the two tanks. Groups of fish held in this system were observed to distribute themselves unequally between the two tanks, despite equal initial stocking and equal feed rations in the two tanks. Social behaviour was established as the controlling factor for this distribution pattern, as aggression and dominance related behaviours by a few individuals in one tank, referred to as the "dominant" tank, drove the majority of the group into the second tank, referred to as the "crowded" tank. The percentage of fish, of the total quantity of fish in the system, occupying the "crowded" tank was used as an indicator of the distribution pattern between the two tanks at three stocking densities; 20 , 40 and $80 \mathrm{~kg} \mathrm{~m}^{-3}$. To support these observations, neuroendocrine indicators of stress, plasma cortisol and brain serotonergic activity, of individuals from the "crowded" tank were examined to determine crowding stress.

2. Materials and Methods

\subsection{Experimental fish}

Rainbow trout from Mark Mølle fish farm, Nykøbing Mors in Denmark were used in the present study. The fish were transported by truck to the Danish Technical University, Institute of Aquatic 
Resources (DTU Aqua) in Hirtshals and upon arrival unloaded directly into quarantine tanks. While in quarantine, the fish were put on a feeding regime at $0.75 \%$ of their total body mass per day. Additionally, the salt content in the water was slowly increased to $15 \%$. The fish were held in quarantine conditions for a period of 15 days, after which they were available to be used for experiments.

Fish were ordered and delivered on two occasions to provide adequate quantities of individuals for all three trials of the experiment. Fish from the first delivery were used in trial 1 and 2 and fish from the second delivery were used in trial 3. The fish originated from the same family.

At the time of arrival, the fish from the first delivery had an average individual weight of $150 \mathrm{~g}$. At the time the fish were used during trial 1 and trial 2, the fish had an average individual weight of $279 \mathrm{~g}$ and $390 \mathrm{~g}$ respectively. At the time of arrival, the fish from the second delivery had an average individual weight of $300 \mathrm{~g}$. At the time the fish were used during trial 3, the fish had an average individual weight of $430 \mathrm{~g}$.

\subsection{Experimental facilities}

The three trials of the experiment were carried out using two-tank systems. Each system consisted of two identical 700 liter circular tanks attached to one another via a doorway. The doorway could be opened by the researcher by removing the sliding door. Each tank was $100 \mathrm{~cm}$ in height and had a diameter of $100 \mathrm{~cm}$. The doorway had a width of $15 \mathrm{~cm}$ and ran the height of the tank. Each tank was individually equipped with a water inflow and outflow, as well as an oxygen and air supply. A water current of approximately $0.5 \mathrm{BL} \mathrm{s}^{-1}$ (body lengths per second) was achieved through small holes in inflow pipe creating pressure, thereby circulating the water around the tank.

Three two-tank systems, standing parallel to each other, were used simultaneously during each trial and were supplied with water from the same recirculating system. The water quality parameters in the system; temperature, ammonia, nitrate, nitrite and $\mathrm{pH}$ were checked daily to ascertain that they were within optimal levels for the fish. The temperature of the water in the system was $16 \pm 0.01{ }^{\circ} \mathrm{C}$, ammonia $\left(\mathrm{NH}_{3} / \mathrm{NH}_{4}{ }^{+}\right)$levels were $0 \mathrm{mg} \mathrm{l}^{-1}$, nitrite $\left(\mathrm{NO}_{2}{ }^{-}\right)$and nitrate $\left(\mathrm{NO}_{3}{ }^{-}\right)$were $37.6 \pm 1.9$ and $0.4 \pm 0.05 \mathrm{mg} \mathrm{l^{-1 }}$ respectively and $\mathrm{pH}$ was $7.6 \pm 0.01$. Oxygen levels were adjusted manually as the fish moved between the 
tanks and kept at levels between 90-100\% saturation in both tanks of each system. The fish were on a $12 / 12$ hour light dark regime, with the lights switching on automatically at 08:00 and switching off at 20:00.

\subsection{Experimental design}

During pilot studies it was observed that when groups of fish were placed in a two-tank system, the result was an unequal distribution of individuals between the two tanks. At the start, an equal quantity of fish was stocked in each tank of the system. Each tank was given the same amount of feed, throughout the study. The doorway was opened allowing individuals to move freely between the two tanks.

The resulting distribution pattern typically observed was one tank becoming occupied by a few dominant aggressive individuals and the majority of the fish occupying the second tank. The few dominant individuals occupying one tank drove out the majority of the group into the second tank, thereby controlling the distribution of the group in the two-tank system. Although quantifications of their behaviour were not made, observation of the fish confirmed that they exhibited behaviour that was characteristic for a dominant inequality in the distribution pattern of groups of fish in the two-tank system to investigate a level of aversiveness to crowding.

Three stocking densities were used during the experiment; the first two-choice system was count and sampling of individuals in the "crowded" tank was determined at two time points during the daily stocked at $20 \mathrm{~kg} \mathrm{~m}^{-3}$, the second at $40 \mathrm{~kg} \mathrm{~m}^{-3}$ and the third at $80 \mathrm{~kg} \mathrm{~m}^{-3}$. The experiment was completed in triplicates as trial 1, trial 2 and trial 3. Between each trial, the stocking density in each two-choice system was changed. The number of fish in each tank was determined every three days during the experiment for a period of two weeks. As the distribution of the fish changed between the night time and the day time, the fish cycle. One time point was chosen at the end of the night time hours, which was in the morning at 07:30 when it was still dark. The second time point was chosen at the end of the day time hours, which was in the 
evening at 19:30 when it was still light. These time points will be referred to as in "dark" and "light", respectively. During the experiment, sampling was alternated between the morning ("dark") and the evening ("light"). Between each trial, the order of the sampling time points was changed. If in trial 1, the first sampling was done in the "dark", then during trial 2, the first sampling was done in the "light" and so on. For each trial, there were a total of four sampling sessions; two at "dark" (session 1 and session 2) and two at "light" (session 1 and session 2).

Additionally, a subsample consisting of six individuals from the "crowded" tank was sampled for blood and brain parts. The individuals were taken before the number of fish in the tank was determined. Plasma cortisol concentrations and brain serotonergic activity were analysed to assess the stress levels in this tank. Cortisol is a commonly used physiological indicator of stress in fish when studying the effects of stocking density (Ellis et al., 2002; North et al., 2006). Additionally, serotonergic activity, the ratio between the brain tissue concentration of serotonin (5-HT, monoamine) and 5-hydroxyindoleacetic acid (5-HIAA, metabolite), has previously been used as an indicator of stress in relation to stocking density in rainbow trout (McKenzie et al., 2012) and has also been used as an indicator of chronic social stress in salmonid fish in pairs and small groups (Øverli et al., 1999; Winberg et al., 1991; Winberg et al., 1992; Winberg and Nilsson, 1993).

\subsection{Experimental procedure}

The fish were transported to the experimental facility and stocked into the three two-tank systems using 20, 40 and $80 \mathrm{~kg} \mathrm{~m}^{-3}$. The two tanks of each system were stocked with equal densities. During this initial stocking process, the number of fish going into each tank was counted to allow for future determination of the percentage of fish occupying each tank. After initial stocking, the fish were given an acclimation period of a week and the doorway separating the two tanks was left closed to hinder any redistribution before the start of the experiment. The fish in each tank of the systems were fed at $1 \%$ of their total body weight (grams) from 08:00 to 20:00 using 12 hour automated belt feeders. After an acclimation period of a week, the doorway between the two tanks in each system was opened, allowing the fish to swim 
freely between the two environments. The amount of feed given to each tank of the two-tank systems was kept at the same level as during the acclimation period.

The number of fish in each tank was determined every three days. For practical reasons, this was done by counting the number of fish in the "dominant" tank and subtracting this count from the total number of known fish in the system. Before determining the number of fish in each tank, a subsample of six individuals from the "crowded" tank of each system were sacrificed by an overdose of anaesthetic (Ethylene glycol monophenyl ether). Blood samples were collected from the caudal vein using $1 \mathrm{ml}$ syringes filled with EDTA (Ethylenedinitrilotetraacetic acid disodium salt dihydrate) powder. The blood samples were centrifuged and the plasma was separated into $1 \mathrm{ml}$ eppendorf tubes and frozen at $-80{ }^{\circ} \mathrm{C}$ for later analysis. Whole brains were dissected out from each fish and separated into four parts; brain stem, hypothalamus, telencephalon and optic lobes, frozen directly using liquid nitrogen and then stored in the $-80{ }^{\circ} \mathrm{C}$ freezer for later analysis.

\subsection{Analysis of plasma cortisol and serotonin}

Cortisol was extracted from the plasma using ethyl ether, evaporated using a vacuum centrifuge and re-suspended in an extraction buffer (ELISA kit extraction buffer). Concentrations (ng ml ${ }^{-1}$ ) were quantified using the ELISA kit standard method (Neogen, Product \#402710).

Frozen brain parts were homogenised in a homogenising reagent (4\% perchloric acid, $0.2 \%$ Ethylenediaminetetraacetic acid, $40 \mathrm{ng} \mathrm{ml}^{-1}$ dihydroxi benzylamine hydroxide solution) and centrifuged at $10,000 \mathrm{rpm}$ at $4{ }^{\circ} \mathrm{C}$ for 10 minutes to separate the supernatant. The supernatant was assayed using High Performance Liquid Chromatography (HPLC) with electrochemical detection, described in Andersson and Höglund (2012), to quantify 5-HIAA (metabolite) and 5-HT (monoamine). The supernatant (sample) was transported through the HPLC system by a mobile phase, which consisted of a buffer solution containing $10.35 \mathrm{~g}^{-1}$ sodium phosphate, $0.3252 \mathrm{~g}^{-1}$ sodium octyl sulphate, $0.0037 \mathrm{~g}^{-1}$ ethylenediaminetetraacetic acid disodium salt dehydrate, $7 \%$ acetonitril in deionised water. The compounds in the sample were analysed using a computer program (software; Clarity, DataApex Ltd.). The sample 5-HIAA and 5-HT quantities were 
compared with quantities from solutions of known concentration (standards) to determine the actual concentrations.

\subsection{Statistical analyses}

The percentage of the total number of fish in one tank was used as a measure of crowding.

The difference in the proportions of fish occupying the "crowded" tank between density treatments $(20,40 \&$

$\left.80 \mathrm{~kg} \mathrm{~m}^{-3}\right)$, sampling time ("dark" and "light"), trial (1, 2 \& 3), two-choice system (1, 2 \& 3) and session (1 crowded tank/total number of fish (binomial distribution).

To determine if there was a difference in the concentrations of plasma cortisol, concentrations of 5-HIAA and 5-HT, and ratios of 5-HIAA/5-HT between density treatments $\left(20,40 \& 80 \mathrm{~kg} \mathrm{~m}^{-3}\right)$,

A Tukey's post hoc test was used to determine between which treatments the significances occurred.

3. Results

\subsubsection{Percentage of fish in the "crowded" tank}

The GENMOD did not indicate any differences between trials $(\mathrm{p}=0.986)$, two choice system $(\mathrm{p}=0.343)$, sampling time $(\mathrm{p}=0.143)$ or session $(\mathrm{p}=0.875)$. The percentage of the fish choosing to be in the crowded environment decreased with increasing total stocking densities $(\mathrm{p}<0.001$, Fig. 1), with a significant difference between stocking densities 20 and $40 \mathrm{~kg} \mathrm{~m}^{-3}(\mathrm{p}=0.007)$, between 20 and $80 \mathrm{~kg} \mathrm{~m}^{-3}(\mathrm{p}<0.001)$ and between 40 and $80 \mathrm{~kg} \mathrm{~m}^{-3}(\mathrm{p}<0.001)$. At $80 \mathrm{~kg} \mathrm{~m}^{-3}$, of a total of $314 \pm 23$ individuals in the system, $251 \pm 27$ occupied the "crowded" tank. At $40 \mathrm{~kg} \mathrm{~m}^{-3}, 125 \pm 11$ out of a total of $144 \pm 9$ individuals 
tank. Furthermore, there was a positive relationship between initial fish weight and density in the crowded $\operatorname{tank}(\mathrm{p}<0.001)$.

\subsubsection{Absolute density in the "crowded" tank}

The absolute density $\left(\mathrm{kg} \mathrm{m}^{-3}\right)$ in the "crowded" tank of the two-tank systems was determined from the percentage of the fish occupying this tank. At stocking density $20 \mathrm{~kg} \mathrm{~m}^{-3}$ the mean absolute density in the "crowded" tank irrespective of sampling time was $32.5 \pm 1.5 \mathrm{~kg} \mathrm{~m}^{-3}$ (Fig. 2). At "dark" and "light" the absolute density was $30.7 \pm 2.3 \mathrm{~kg} \mathrm{~m}^{-3}$ and $34.3 \pm 2.1 \mathrm{~kg} \mathrm{~m}^{-3}$ respectively. At $40 \mathrm{~kg} \mathrm{~m}^{-3}$ the mean absolute density was $63.7 \pm 2.4 \mathrm{~kg} \mathrm{~m}^{-3}$ (Fig. 2), and $57.4 \pm 3.5 \mathrm{~kg} \mathrm{~m}^{-3}$ and $69.9 \pm 3.3 \mathrm{~kg} \mathrm{~m}^{-3}$ in the "dark" and "light" respectively. At $80 \mathrm{~kg} \mathrm{~m}^{-3}$ the mean absolute density was $126.5 \pm 3.7 \mathrm{~kg} \mathrm{~m}^{-3}$ (Fig. 2), and in the "dark" and "light" was $115.7 \pm 5.5 \mathrm{~kg} \mathrm{~m}^{-3}$ and $137.4 \pm 10.0 \mathrm{~kg} \mathrm{~m}^{-3}$ respectively.

\subsection{Neuroendocrine indicators of stress}

\subsubsection{Plasma cortisol}

Despite a tendency for slight elevation in the plasma cortisol concentrations of individuals in the "crowded" tank at the highest total density stocked $\left(\mathrm{kg} \mathrm{m}^{-3}\right)$, there was no difference in the levels between the three densities stocked (20, $40 \& 80 \mathrm{~kg} \mathrm{~m}^{-3}$; $\mathrm{p}=0.314$; Fig. 3). There was also no significant difference between the "dark" and "light" (sampling time; $p=0.140$ ), between the first and second sampling session (

\subsubsection{Brain ratios (5-HIAA/5-HT)}

Generally, the serotonergic activity in the brain stem of the individuals in the "crowded" tank was higher in the "light" compared to the "dark" irrespective of stocking density ( $\mathrm{p}=0.013)$ and higher in the first sampling session compared to the second sampling session irrespective of density (session; $\mathrm{p}=0.001$ ). Moreover, there was a higher activity level in the individuals in the "crowded" tank of the system stocked at $80 \mathrm{~kg} \mathrm{~m}^{-3}$, compared to the individuals in the two systems stocked at 20 and $40 \mathrm{~kg} \mathrm{~m}^{-3}$ (p<0.001; Fig. 4A). Specifically, there were no differences in activity levels between 20 and $40 \mathrm{~kg} \mathrm{~m}^{-3}$ ( $\left.\mathrm{p}=0.953\right)$, but 
differences between 20 and $80 \mathrm{~kg} \mathrm{~m}^{-3}$ ( $\left.\mathrm{p}<0.001\right)$ and between 40 and $80 \mathrm{~kg} \mathrm{~m}^{-3}$ ( $\mathrm{p}<0.001$; Fig. 4A). Furthermore, there was an effect of trial $(\mathrm{p}=0.028)$. Fish weight showed a negative relationship with serotonergic activity $(\mathrm{p}=0.004)$.

The serotonergic activity in the telencephalon of the individuals in the "crowded" tank followed a similar pattern. Activity levels were higher in the individuals in the "light" compared to the "dark" irrespective of density (sampling time; $\mathrm{p} \leq 0.001$ ). In contrast to the brain stem, serotonergic activity was higher in the second sampling session compared to the first (session; $\mathrm{p} \leq 0.001$ ). Furthermore, in the telencephalon there was only a trend towards higher serotonergic activity in the individuals in the "crowded" tank of the system stocked at $80 \mathrm{~kg} \mathrm{~m}^{-3}$, compared to 20 and $40 \mathrm{~kg} \mathrm{~m}^{-3}$ ( $\mathrm{p}=0.064$; Fig. 4B). There was no effect of trials ( $\mathrm{p}=0.919)$ or fish weight $(0.518)$.

The 5-HTergic activity in the hypothalamus of the individuals in the "crowded" tank, of all systems combined, did not differ between the "dark" and "light" (sampling time; $\mathrm{p}=0.127$ ), between the first and second sampling session $(\mathrm{p}=0.064)$, between trial $(\mathrm{p}=0.058)$, fish weight $(\mathrm{p}=0.109)$ or the total densities stocked ( $\mathrm{p}=0.263$; Fig. 4C).

\subsubsection{Brain 5-HT and 5-HIAA}

The concentration of the main metabolite (5-HIAA) of serotonin and monoamine serotonin (5-HT) in the brain stem, telencephalon and hypothalamus between the three density treatments $(20,40, \& 80$ $\mathrm{kg} \mathrm{m}^{-3}$ ) are given in Table 1.

In the brain stem, there was a significant effect on 5-HIAA concentration by sampling time $(\mathrm{p}=0.013)$, session $(\mathrm{p}=0.001)$ and density treatment $(\mathrm{p}=0.012)$ and trial $(\mathrm{p}=0.011)$, but there was no effect of fish weight $(\mathrm{p}=0.468)$. There was a significant difference in 5-HT concentration between session $(\mathrm{p}<0.001)$ and trial $(\mathrm{p}=0.001)$, but not sampling time $(\mathrm{p}=0.301)$, fish weight $(\mathrm{p}=0.368)$ or density treatment $(0.703)$.

In the telencephalon, there was a difference in 5-HIAA concentration between sampling time $(\mathrm{p}=0.012)$, but not between trials $(\mathrm{p}=0.069)$, session $(\mathrm{p}=0.975)$, fish weight $(\mathrm{p}=0.329)$ or density treatment $(\mathrm{p}=0.345)$. A similar pattern was observed in 5-HT concentrations, where an effect of sampling time 
$(\mathrm{p}<0.001)$ and trials $(\mathrm{p}<0.001)$ was observed. However, no effect of session $(\mathrm{p}=0.116)$, fish weight $(\mathrm{p}=0.846)$ 293 or density treatment $(\mathrm{p}=0.146)$ were detected.

In the hypothalamus, there was a difference in 5-HIAA concentration between sampling time $(\mathrm{p}=0.008)$, trials $(\mathrm{p}<0.001)$, session $(\mathrm{p}=0.044)$, but not fish weight $(0.173)$ or density treatment $(\mathrm{p}=0.321)$. In 5-HT concentrations there was a difference between session $(\mathrm{p} \leq 0.001)$, trials $(\mathrm{p}<0.001)$, but not sampling time $(\mathrm{p}=0.986)$, fish weight $(\mathrm{p}=0.643)$ or density treatment $(\mathrm{p}=0.798)$.

4. Discussion

In the present study, the distribution of the fish in the two-tank systems was unequal, irrespective of total density, with a few highly aggressive dominant individuals controlling one tank ("dominant" tank) and the majority of the fish preferring to occupy the second tank ("crowded" tank). This distribution pattern resembled an Ideal Despotic Distribution (IDD), first described in birds, where tank and fish attempting to enter the tank. Furthermore, it was observed that with increasing density, apart from the few dominant aggressive individuals occupying the "dominant" tank, there was a spillover of individuals from the "crowded" tank entering the "dominant" tank that did not perform aggressive acts. These individuals stayed immobile and accumulated in the "dominant" tank close to the doorway between the two tanks, a behaviour which is typically observed in subordinate fish (Abbott et al., 1985; Øverli et al., 1999; Winberg and Nilsson, 1993; Øverli et al., 1998). This distribution pattern was especially distinct in the two-tank system stocked with the highest total density, with the "dominant" tank occupied by a few dominant aggressive individuals and a gradual accumulation of subordinate individuals. The results indicated a negative relationship between the percentage of fish in the "crowded" tank and the total density stocked. 
Specifically, the percentage of fish in the "crowded" tank decreased significantly with increasing total stocking density $\left(20,40\right.$ and $\left.80 \mathrm{~kg} \mathrm{~m}^{-3}\right)$. As a result of this distribution pattern in the tanks, irrespective of the time of day (sampling time, "dark" or "light"), the mean absolute density in the "crowded" tank stocked at a total density of $20 \mathrm{~kg} \mathrm{~m}^{-3}$ was $33 \mathrm{~kg} \mathrm{~m}^{-3}$, at $40 \mathrm{~kg} \mathrm{~m}^{-3}$ was $64 \mathrm{~kg} \mathrm{~m}^{-3}$, and $80 \mathrm{~kg} \mathrm{~m}^{-3}$ was $127 \mathrm{~kg} \mathrm{~m}$ ${ }^{3}$. Moreover, although not significantly different, the spatial distribution was observed to be more unequal during the hours when it was light (evening sampling) than during the hours when it was dark (morning sampling). During the day the fish were provided with a food resource to compete for, resulting in a few individuals monopolising this resource in one tank ("dominant" tank) and driving out the majority of the individuals into the second tank ("crowded" tank).

Neuroendocrine indicators of stress were examined to support our behavioural observations. Interestingly, the significantly higher serotonergic activity found in the brain stem and telencephalon of the individuals in the "crowded" tank under light conditions, irrespective of density, indicated higher stress levels in these fish. This suggests that stronger social competition in the "dominant" tank during the day led to greater inequality in the observed distribution of the fish in the two-choice systems which resulted in higher stress levels in the "crowded" tank. Furthermore, we observed elevated serotonergic activity, as 5HIAA concentrations and 5-HIAA/5-HT ratios, in the brain stem and a tendency for elevated levels in the telencephalon of the individuals in the "crowded" tank of the system stocked at the highest density $\left(80 \mathrm{~kg} \mathrm{~m}^{-}\right.$ ${ }^{3}$ ). Previous studies investigating social behaviour in pairs or small groups of fish found an elevation in serotonergic activity levels in individuals exposed to prolonged periods of social stress (socially subordinate individuals) (Øverli et al., 1999; Winberg et al., 1991; Winberg et al., 1992; Winberg and Nilsson, 1993), as indicated by elevated concentrations of 5-HIAA and 5-HIAA/5-HT ratios (Winberg and Nilsson, 1993; Winberg and Lepage, 1998). Often in parallel to this is an elevation in plasma cortisol concentration, suggesting a stimulatory role of 5-HT activity on the HPI axis (Øverli et al., 1999). However, this relationship tends to weaken during prolonged stress, where HPI axis reactivity decreases while 5-HT activity remains high (Winberg and Lepage, 1998). Indeed, the plasma cortisol levels found in the individuals in the "crowded" tank of the two-choice systems in the present study were generally low, and did 
not co-vary with serotonergic activity. Nevertheless, these findings are not uncommon in Salmonids. Basal 345 levels of plasma cortisol in unstressed fish below $5 \mathrm{ng} \mathrm{ml}^{-1}$, usually between $1-2 \mathrm{ng} \mathrm{ml}^{-1}$, have been found, and in chronically stressed individuals, below $10 \mathrm{ng} \mathrm{ml}^{-1}$ (Pickering and Stewart, 1984; Pickering and Pottinger, 1989). In some cases, when subjected to chronic stress, plasma cortisol levels (10 $\left.\mathrm{ng} \mathrm{ml}^{-1}\right)$ eventually returned to basal levels $\left(\mathrm{ng} \mathrm{ml}^{-1}\right.$ ) after a period of time, despite the continued presence of stress (Barton et al., 1980; Pickering, 1992; Strange and Schreck, 1978). Hence, in the present study, elevated levels of serotonergic activity and low concentrations of cortisol in the "crowded" tank of the two-choice system stocked at $80 \mathrm{~kg} \mathrm{~m}^{-3}$ should reflect chronic stress in a crowded situation. to be at a higher density than smaller individuals. The negative relationship between fish weight and serotonergic activity in the brain stem suggests that of the fish that have accepted to stay in the "crowded" tank, the smaller fish had higher stress levels compared to larger fish. Additional studies are needed to assess how fish size influences the distribution of fish, but our results indicate that fish size is an important factor to additional studies are necessary to exclude the influence of this factor. consider when investigating critical stocking densities. Furthermore, although water quality parameters were checked at a system level daily, they were not measured specifically at the tank level. It may be speculated that as there was such a high number of fish in the "crowded" tank of the system stocked at the highest density, the water quality may have been influenced. As a result, we cannot exclude the fact that the density effects observed on the neuroendocrine stress levels could be, in part, influenced by water quality. Therefore,

\section{Conclusion}

Here we have presented a method using two-tank systems to determine a level of crowding that showed signs of aversiveness in farmed rainbow trout. A negative relationship between stocking density and the percentage of fish occupying the "crowded" tank was observed. Furthermore, the neuroendocrine indicators of stress suggested the presence of chronic stress in the fish of the two-tank system stocked at the highest density $\left(80 \mathrm{~kg} \mathrm{~m}^{-3}\right)$, with low concentrations of plasma cortisol but elevated levels of serotonergic activity found in the brain stem of the individuals in the "crowded" tank of this system. Overall, these results 
371 indicated that a level of aversiveness to crowding had been reached at the highest total density stocked,

372 where the mean absolute density that was observed in the "crowded" tank was $126.5 \pm 3.7 \mathrm{~kg} \mathrm{~m}^{-3}$. A follow 373 up study is necessary to assess if being held at the densities accepted by the fish in the present study has an 374 impact on indicators of welfare and performance in farmed rainbow trout.

375

6. Acknowledgements

This study was funded by the Danish Ministry of Food, Agriculture and Fisheries. We thank

Ole Madvig Larsen, Rasmus Freydenlund Jensen, Erik Poulsen and Alfred Jokumsen from the Danish Technical University, Institute of Aquatic Resources for their practical assistance with the fish.

\section{References}

382 Andersson, M.Å., Höglund, E. Linking personality to larval energy reserves in rainbow trout (Oncorhynchus mykiss). PLoS ONE 7(11): e49247

Abbott, J., Dunbrack, R., Orr, C., 1985. The Interaction of Size and Experience in Dominance Relationships of Juvenile Steelhead Trout (Salmo gairdneri). Behaviour 92, 241-253.

Bagley, M., Bentley, B., Gall, G., 1994. A Genetic Evaluation of the Influence of Stocking Density on the Early Growth of Rainbow Trout (Oncorhynchus mykiss). Aquaculture 121, 313-326. gairdneri) at Rest, and Subjected to Handling, Confinement, Transport, and Stocking. Can. J. Fish. Aquat. Sci. $37,805-811$. trout in relation to stocking density and food accessibility. Aquacult. Res. 33, 1233-1242. 
Brännäs, E., Johnsson, J., 2008. Behaviour and welfare in farmed fish. In: Fish Behaviour, Magnhagen, C., Braithwaite, V.A., Forsgren, E., Kapoor, B.G. (Eds.), 1 ed. Science publishers, Ensfield, New Hampshire, pp. 593-627.

Ellis, T., North, B., Scott, A., Bromage, N., Porter, M., Gadd, D., 2002. The relationships between stocking density and welfare in farmed rainbow trout. J. Fish Biol. 61, 493-531.

Fretwell, S.D., 1972. Populations in a Seasonal Environment, Monographs in Population Biology 5 ed. Princeton University Press, United States of America.

Hakoyama, H., Iguchi, K., 2001. Transition from a random to an ideal free to an ideal despotic distribution: the effect of individual difference in growth. J. Ethol. 19, 129-137.

Huntingford, F., Adams, C., Braithwaite, V., Kadri, S., Pottinger, T., Sandoe, P., Turnbull, J., 2006. Current issues in fish welfare. J. Fish Biol. 68, 332-372.

Larsen, B.K., Skov, P.V., McKenzie, D.J., Jokumsen, A., 2012. The effects of stocking density and low level sustained exercise on the energetic efficiency of rainbow trout (Oncorhynchus mykiss) reared at 19 degrees C. Aquaculture 324, 226-233.

Maclean, A., Huntingford, F., Ruxton, G., Morgan, I., Hamilton, J., Armstrong, J., 2005. Testing the assumptions of the ideal despotic distribution with an unpredictable food supply: experiments in juvenile salmon. J. Anim. Ecol. 74, 214-225.

McKenzie, D.J., Höglund, E., Dupont-Prinet, A., Larsen, B.K., Skov, P.V., Pedersen, P.B., Jokumsen, A., 2012. Effects of stocking density and sustained aerobic exercise on growth, energetics and welfare of rainbow trout. Aquaculture 338, 216-222.

North, B., Turnbull, J., Ellis, T., Porter, M., Migaud, H., Bron, J., Bromage, N., 2006. The impact of stocking density on the welfare of rainbow trout (Oncorhynchus mykiss). Aquaculture 255, 466-479. 
415 Øverli, Ø., Harris, C., Winberg, S., 1999. Short-term effects of fights for social dominance and the 416 establishment of dominant-subordinate relationships on brain monoamines and cortisol in rainbow trout.

417 Brain Behav. Evol. 54, 263-275.

418 Øverli, Ø., Winberg, S., Damsgård, B., Jobling, M., 1998. Food intake and spontaneous swimming activity 419 in Arctic char (Salvelinus alpinus): role of brain serotonergic activity and social interactions. Can. J. Zool. 420 Rev. Can. Zool. 76, 1366-1370.

421 Person-Le Ruyet, J., Labbe, L., Le Bayon, N., Severe, A., Le Roux, A., Le Delliou, H., Quemener, L., 2008. 422 Combined effects of water quality and stocking density on welfare and growth of rainbow trout 423 (Oncorhynchus mykiss). Aquat. Living Resour. 21, 185-195.

424 Pickering, A., 1992. Rainbow Trout Husbandry - Management of the Stress Response. Aquaculture 100, $425 \quad 125-139$.

426 Pickering, A., Pottinger, T., 1989. Stress Responses and Disease Resistance in Salmonid Fish - Effects of 427 Chronic Elevation of Plasma Cortisol. Fish Physiol. Biochem. 7, 253-258. Pickering, A., Stewart, A., 1984. Acclimation of the Interrenal Tissue of the Brown Trout, Salmo trutta L, to Chronic Crowding Stress. J. Fish Biol. 24, 731-740. reared at different sizes, densities and feeding frequencies in high-temperature re-circulated water. Aquacult. Int. 15, 97-107. (Oncorhyynchus tshawytscha). Trans. Am. Fish. Soc. 107, 812-819.

435 Winberg, S., Lepage, O., 1998. Elevation of brain 5-HT activity, POMC expression, and plasma cortisol in 436 socially subordinate rainbow trout. Am. J. Physiol. -Regul. Integr. Comp. Physiol. 274, R645-R654. 
437 Winberg, S., Nilsson, G., 1993. Roles of Brain Monoamine Neurotransmitters in Agonistic Behavior and 438 Stress Reactions, with Particular Reference to Fish. Comp. Biochem. Physiol. C-Pharmacol. Toxicol. 439 Endocrinol. 106, 597-614.

440 Winberg, S., Nilsson, G., Olsen, K., 1992. Changes in Brain Serotonergic Activity during Hierarchical 441 Behavior in Arctic Charr (Salvelinus alpinus L) are Socially Induced. J. Comp. Physiol. A-Sens. Neural 442 Behav. Physiol. 170, 93-99.

443 Winberg, S., Nilsson, G., Olsen, K., 1991. Social Rank and Brain Levels of Monoamines and Monoamine 444 Metabolites in Arctic-Charr, Salvelinus alpinus (L). J. Comp. Physiol. A-Sens. Neural Behav. Physiol. 168, $445 \quad 241-246$.

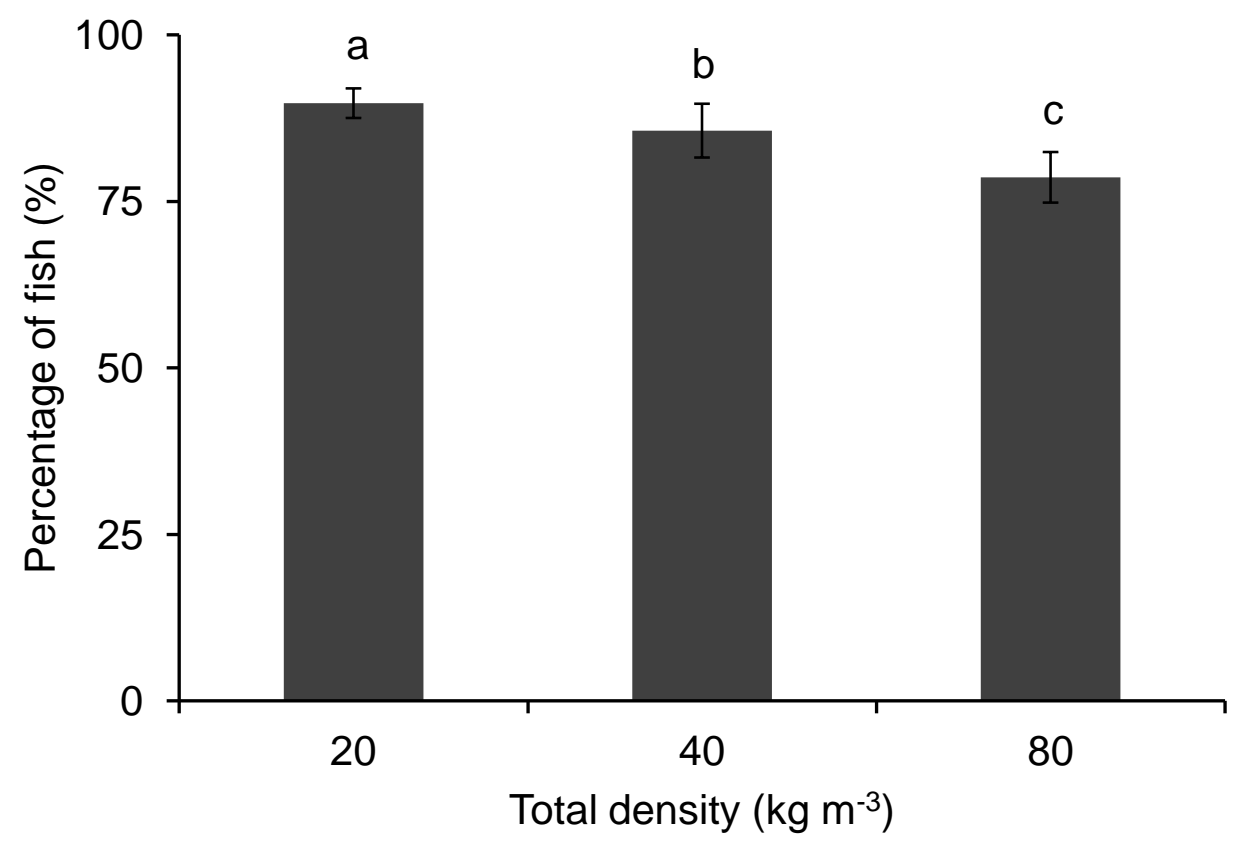

449 Figure 1. The percentage of fish in the "crowded" tank of the two-choice system between the three total 450 densities $(n=3)$. The letters $(a, b$ \& $c)$ indicate a significant difference between treatments. 


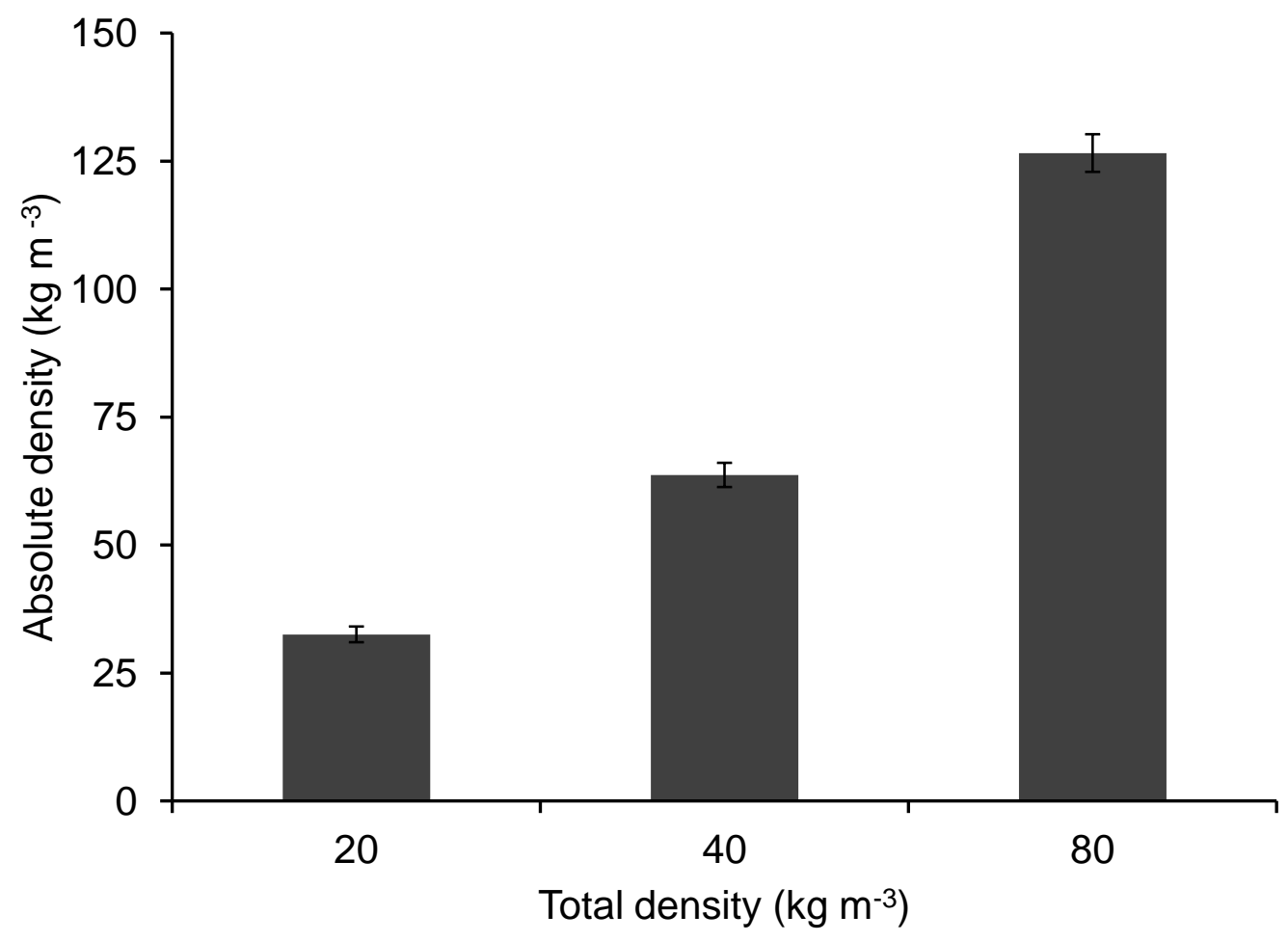

453

454 Figure 2 . The absolute density $\left(\mathrm{kg} \mathrm{m}^{-3}\right)$ in the "crowded" tank at each total density $(\mathrm{n}=3)$.

455

456

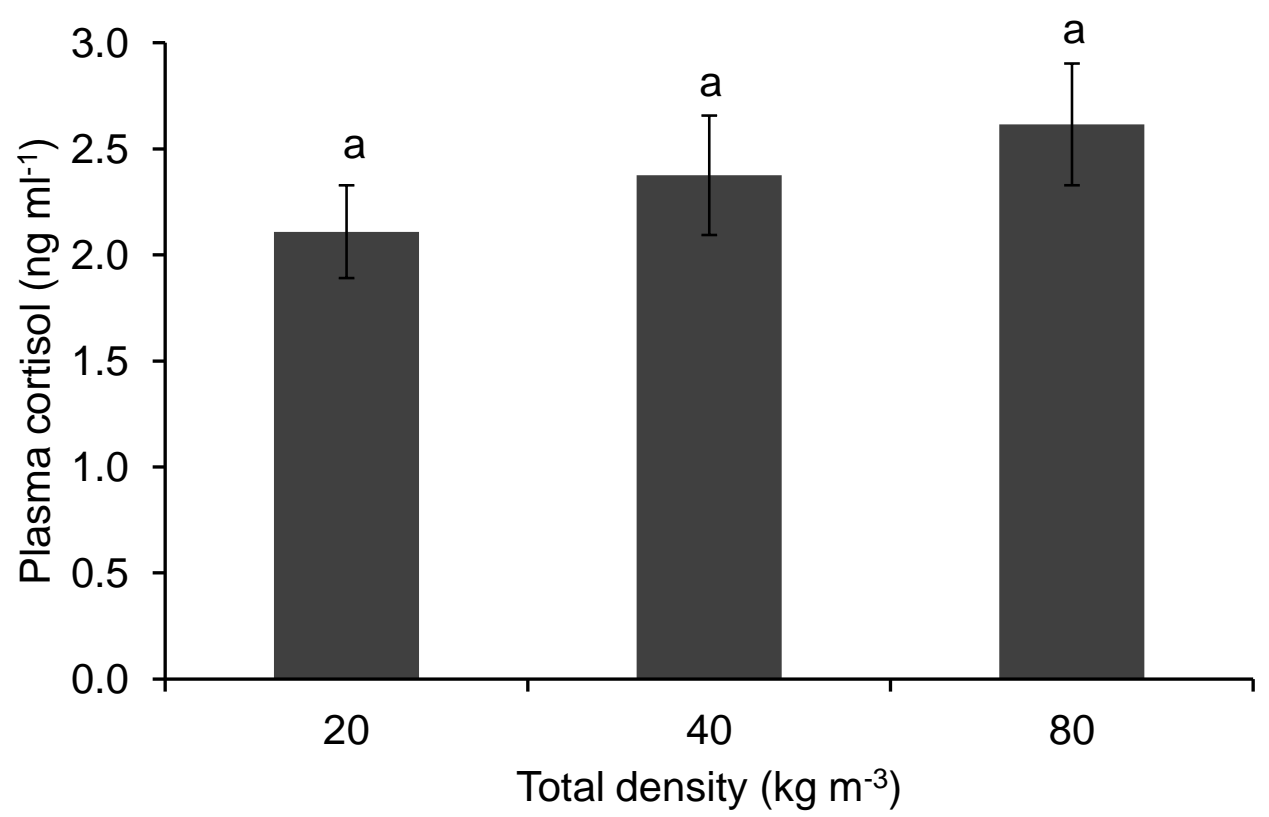

457 Figure 3. Plasma cortisol concentrations of individuals taken from the "crowded" tank at each total density $458 \quad(n=18)$. 


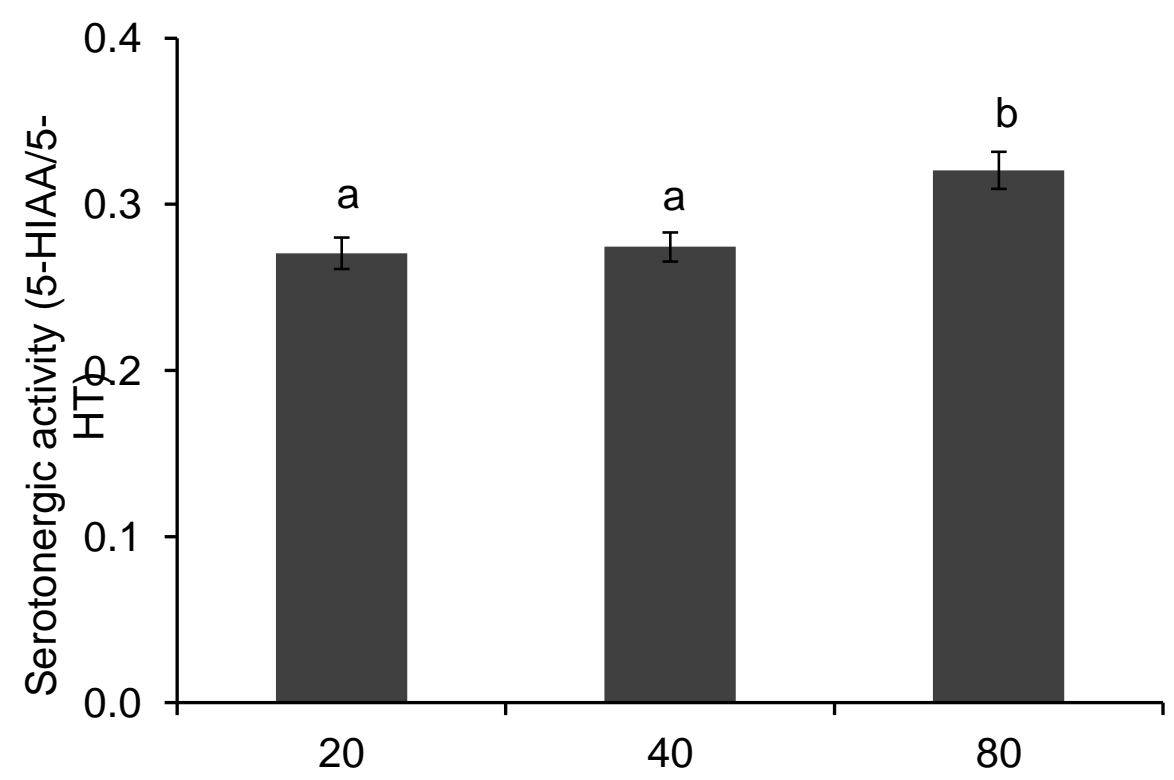
a) Brain stem
Total density $\left(\mathrm{kg} \mathrm{m}^{-3}\right)$

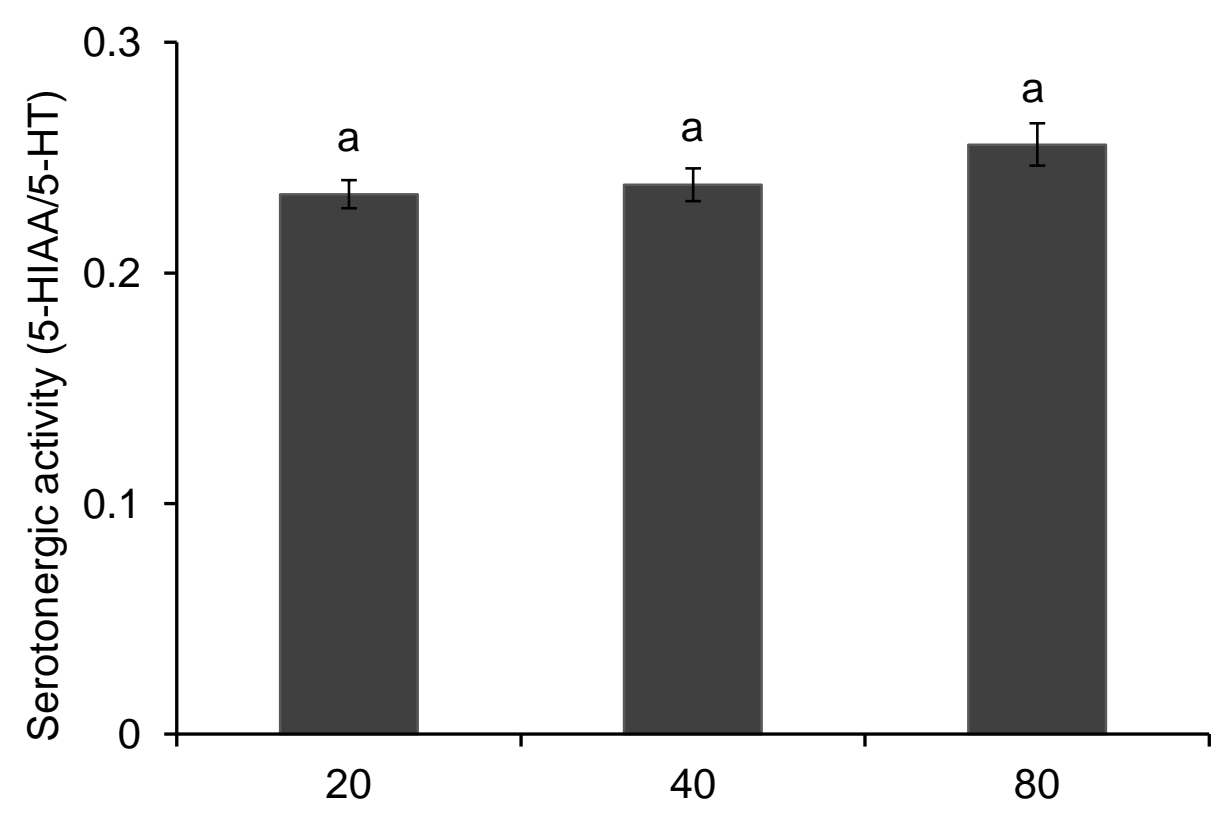

Total density $\left(\mathrm{kg} \mathrm{m}^{-3}\right)$ 


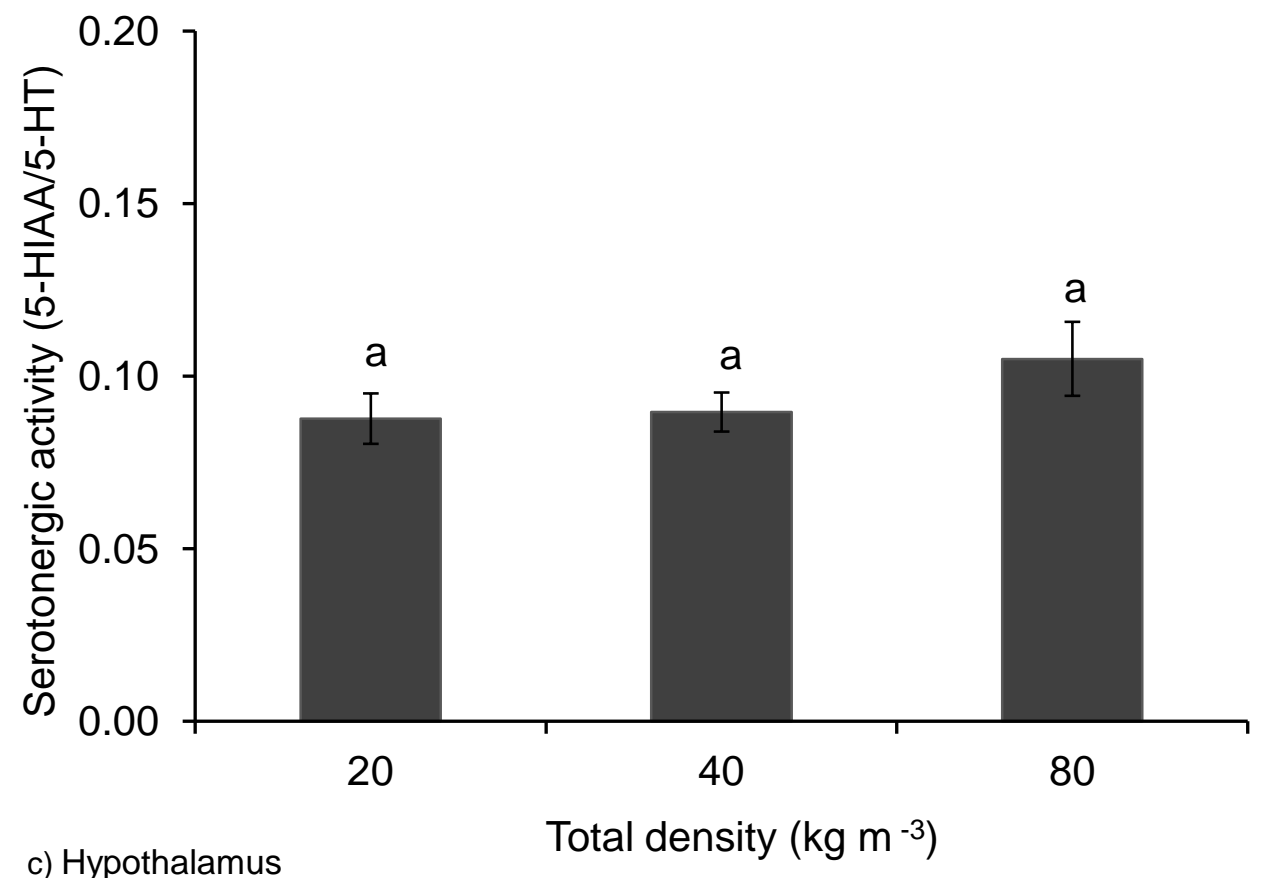

464 Figure 4. Serotonergic activity (5-HIAA/5-HT) in the a) Brain stem, b) Telencephalon and c) Hypothalamus 465 of individuals $(n=18)$ in the "crowded" tank at each total density. The letters (a \& b) indicate a significant 466 difference between treatments.

467

468 9. Table captions

469 Table 1 . The concentrations (mean \pm SEM) of monoamine and metabolites in the different brain regions of 470 the individuals $(\mathrm{n}=18)$ in the "crowded" tank at each total density.

\section{Density treatment $\left(\mathrm{kg} \mathrm{m}^{3-1}\right)$}

\begin{tabular}{lccccc}
\hline Brain region & $\begin{array}{c}\text { Metabolite } \\
\text { and } \\
\text { metabolite }\end{array}$ & $\mathbf{2 0}$ & $\mathbf{4 0}$ & $\mathbf{8 0}$ & p value \\
\hline Brain stem & 5-HIAA & $363.1 \pm 21.0$ & $404.5 \pm 23.4$ & $438.9 \pm 19.7$ & 0.013 \\
Telencephalon & 5-HT & $1419.5 \pm 89.3$ & $1574.7 \pm 113.6$ & $1444.9 \pm 67.7$ & 0.653 \\
& 5-HIAA & $1094.9 \pm 55.7$ & $1161.1 \pm 51.3$ & $1077.8 \pm 47.9$ & 0.398 \\
Hypothalamus & 5-HT & $4954.33 \pm$ & $5201.8 \pm 277.9$ & $4550.1 \pm 230.2$ & 0.190 \\
& 5-HIAA & $390.5 \pm 17.3$ & $410.7 \pm 25.8$ & $457.8 \pm 29.5$ & 0.439 \\
& 5-HT & $5589.9 \pm 373.0$ & $5326.3 \pm 372.0$ & $5633.1 \pm 420.9$ & 0.850
\end{tabular}

